\title{
A Study about Submarine Sewage Outfalls in the Coastal Region of the State of Paraná - Brazil $\left(26^{\circ} \mathrm{S} 48^{\circ} \mathrm{W}\right)$
}

\author{
Joseph Harari ${ }^{1}$, Paola Galluzzi Polesi ${ }^{1}$, Tiago Cortez ${ }^{1}$ and Samuel Hora Yang ${ }^{2}$ \\ ${ }^{1}$ Instituto Oceanográfico da Universidade de São Paulo, Brazil \\ ${ }^{2}$ Instituto de Energia e Ambiente, da Universidade de São Paulo (IEE-USP), Brazil
}

Submission: February 04, 2019; Published: February 15, 2019

*Corresponding author: Joseph Harari, Instituto Oceanográfico da Universidade de São Paulo, Brazil

\begin{abstract}
The following study aims to investigate the dispersion of pollutants in the coastal region of the State of Paraná, located on the southeastern continental shelf of Brazil, which includes two important estuarine systems, Paranaguá Estuarine Complex and Guaratuba Bay. Initially, hydrodynamic simulations were performed through the Delft3D modeling system, with the hydrodynamic module (FLOW); subsequently, the dispersion of pollutants was evaluated, using the Delft3D water quality module (WAQ). Considering that submarine sewage outfalls constitute an excellent solution for an efficient and sustainable management of effluents, the question to be addressed in the study is the possibility of evaluating this solution through numerical modeling. The results of the models are indicative of the best locations for the construction of submarine emissaries, thus constituting an important subsidy in the treatment of sewage in the coast of the State of Paraná, especially for coastal cities that suffer great environmental pressure due to activities related to tourism, fishing and maritime transport. The conclusion of the research is that the implementation and management of submarine outfalls must be done with suitable modeling of both hydrodynamics and dispersion, together with monitoring programs based on field measurements, to validate the models.
\end{abstract}

Keywords: Numerical modeling; Delft3D; Pollutant dispersion; Submarine outfall

Abbreviations: NCEP: National Centers for Environmental Prediction; CFS: Climate Forecast System; WAQ: Water Quality Module

\section{Introduction}

The State of Paraná is located at the southern region of Brazil, comprising two important estuarine systems, Paranaguá Estuarine Complex and Guaratuba Bay (Figure 1).

The climatology of the region and the circulation on the platform are governed by the presence of two meteorological systems: The Tropical Anticyclone (South Atlantic High) and the Polar Migratory Anticyclone. The winds from NE and E directions that occur on the continental shelf are associated with the presence of the Tropical Anticyclone, having an average intensity of $4 \mathrm{~m} . \mathrm{s}^{-1}[1]$, so the currents on the platform have predominant $\mathrm{S}$ SW directions [2]. The occurrence of frontal systems in the region is associated to the trajectory of the Polar Migratory Anticyclone, which propagates to $\mathrm{N}$ and NE directions [3]; during these meteorological events, winds from South may become strong and persistent enough to reverse the circulation on the platform, forcing Northeast currents [2]. During the summer the cold fronts are less frequent, while in winter they are generally more frequent and stronger [4].

The dynamic of the Southeast Brazilian platform is therefore dominated by wind forcing, but tidal circulation may also be im portant. The tidal currents are weaker and rotating in time, whereas the currents generated by the winds are persistent and stronger, parallel to the coast, predominantly to the West-Southwest, but turning to East-Northeast (and usually more intense) under the influence of frontal systems. However, within the Paranaguá Estuarine Complex and Guaratuba Bay, and adjacent coastal areas, the hydrodynamics is governed by two main forcings: fluvial discharges and tides. By continuity, the tidal currents are very intense at the entry channels of these estuaries [5].

The discharge of domestic sewage is one of the most common types of ocean pollution, either through diffuse pollution in watercourses or through concentrated sources, such as submarine outfalls. A submarine emissary consists of a long pipeline, implanted on the seabed, from which the effluents are released in deeper regions, thus allowing effective dilution [6].

In general, the amount to be disbursed in an emissary construction is much larger than in a sewage treatment plant. The latter can be built in stages, considering the populational demand, while the emissary must be built at once. However, when comparing reference values between a sewage plant and an emissary, per 
capita costs are lower for the second [7]. In addition, the advantages of a submarine outfall are numerous, including high efficiency of sewage treatment and disposal, absence of visual pollution and odors, low energy expenditure, low maintenance requirements and less occupation of land [8].

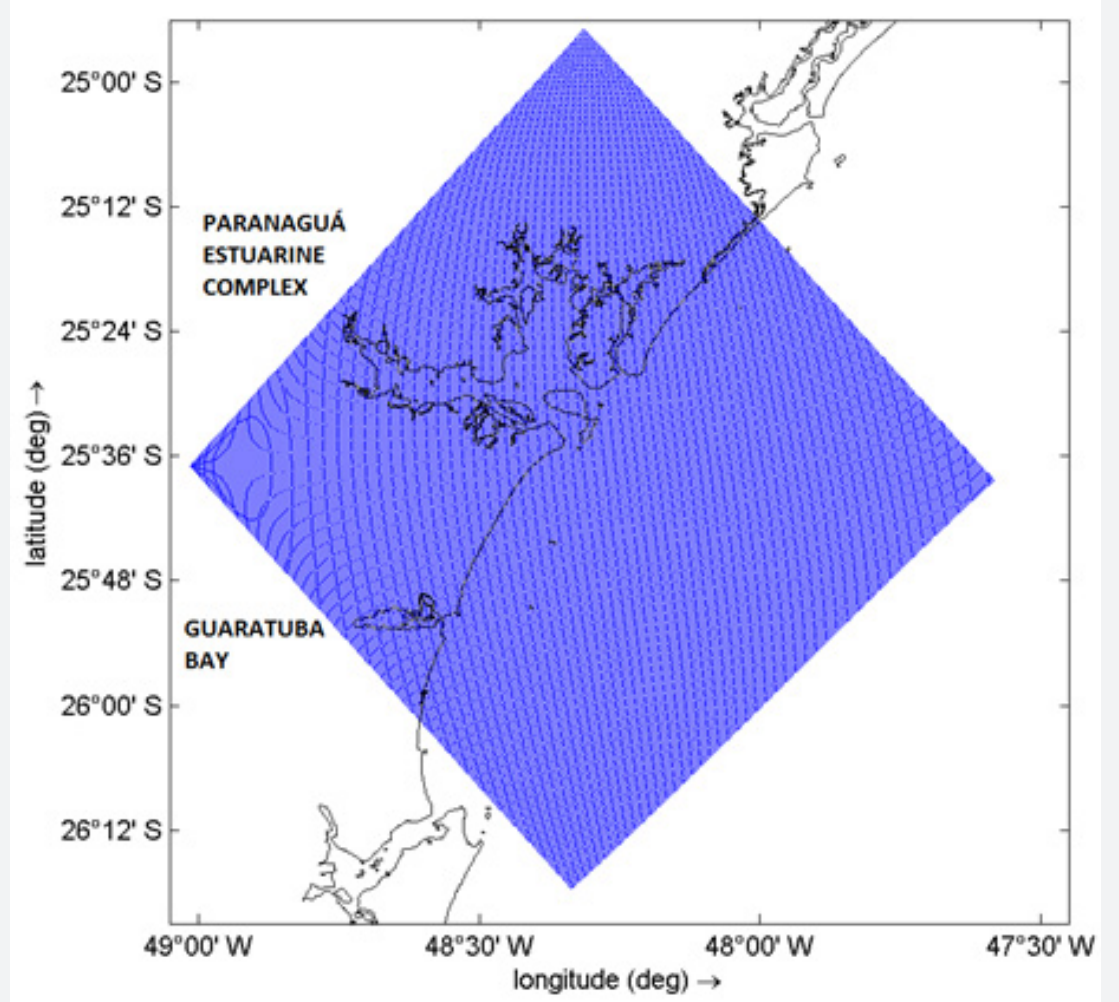

Figure 1: Study area and computational grid used for the hydrodynamic and water quality modeling.

Submarine emitters represent an extremely efficient way of managing effluents resulting from large population centers. Both Paranaguá Estuary and Guaratuba Bay have enormous urban pressure due to the rapid and disorganized development of their cities, mostly due to tourism, fishing and maritime transport activities. An excellent option to improve the existing flaws in the region's basic sanitation system is the construction of sewage emissaries.

In fact, approximately 160.00 people live on the shores of the Paranaguá Estuarine Complex, which also comprises two major maritime ports, of Paranaguá and Antonina, the former being the largest port complex for solid cargo shipments in Latin America [9]. The region's sewage treatment system is increasingly suffering from high demand for quality services, especially during summer season, due to an enormous affluence of tourists.

The detailed study of hydrodynamics in the coastal region is necessarily the first step in the decision making of the emissary implementation process. Without this information, the construction may not be efficient in recycling discharged organic material, resulting in considerable environmental damage.

Considering that submarine sewage outfalls constitute an excellent solution for an efficient and sustainable management of domestic effluents, the question to be addressed in present study is on the possibility of evaluating the efficiency of submarine outfalls, for the dispersion of sewage in the region of interest, through numerical modeling. The hypothesis adopted is that the results of the modeling are indicative of the best sites for the construction of submarine emissaries. Therefore, as a result of this study, from the analysis of circulation and dispersion, possible locations for the installation of submarine emissaries were evaluated, seeking to improve the local sewage treatment.

\section{Material and Methods}

The hydrodynamics and dispersion of pollutants simulations along the coast of the State of Paraná were carried out using the Delft3D modeling system [10], considering its hydrodynamic module (FLOW) and water quality module (WAQ). To form a full analysis of the processes that occurs in the study area, simulations were performed for the month of January 2016, representing summer conditions, and for the month of July 2016, representing winter conditions. The comparison of model results allows thus for a complete analysis of the hydrodynamic and water quality conditions of the region.

The hydrodynamic model implemented in this study used an Arakawa Type $\mathrm{C}$ grid, built in spherical coordinates, with grid spacing around $350 \mathrm{~m}$, containing 300 points both in the directions parallel and perpendicular to the coast, as shown in Figure 1. 
In this study, data of mean sea level and tidal elevation, together with currents, temperature and salinity profiles, were used as forcing at the open contours of the grid. In addition, the wind shear stress and radiation fluxes were applied at the sea surface of the whole study area. All the boundary conditions were taken from validated global models, frequently used in the most diverse studies, and recognized for their reliability. Both meteorological and oceanographic boundary data were interpolated into one-hour intervals.

Surface wind and radiation data were extracted from the global atmospheric model of National Centers for Environmental Prediction (NCEP) Climate Forecast System (CFS) [11], being interpolated in space and time, for grid points and for hourly intervals.
Tidal data for the open contours of the grid were obtained through the Oregon State University TOPEX/Poseidon Global Inverse Solution (TPXO) database [12], for constituents M2, S2, N2, K2, K1, 01, P1, Q1, Mf, Mm, M4, MS4, MN4 [13].

Vertical profiles of temperature and salinity at the open contours of the study area were extracted from outputs of global models of CMEMS - Copernicus Marine Environment Monitoring Services $[14,15]$. These models also provided current profiles and mean sea level oscillations at the open boundaries, associated to meteorological and density effects. Finally, the Riemann invariant, which combines water level and current data, was used at the open boundaries of the grid as flow forcing [16]. CMEMS ocean models have horizontal resolution of approximately $9 \mathrm{~km}$.

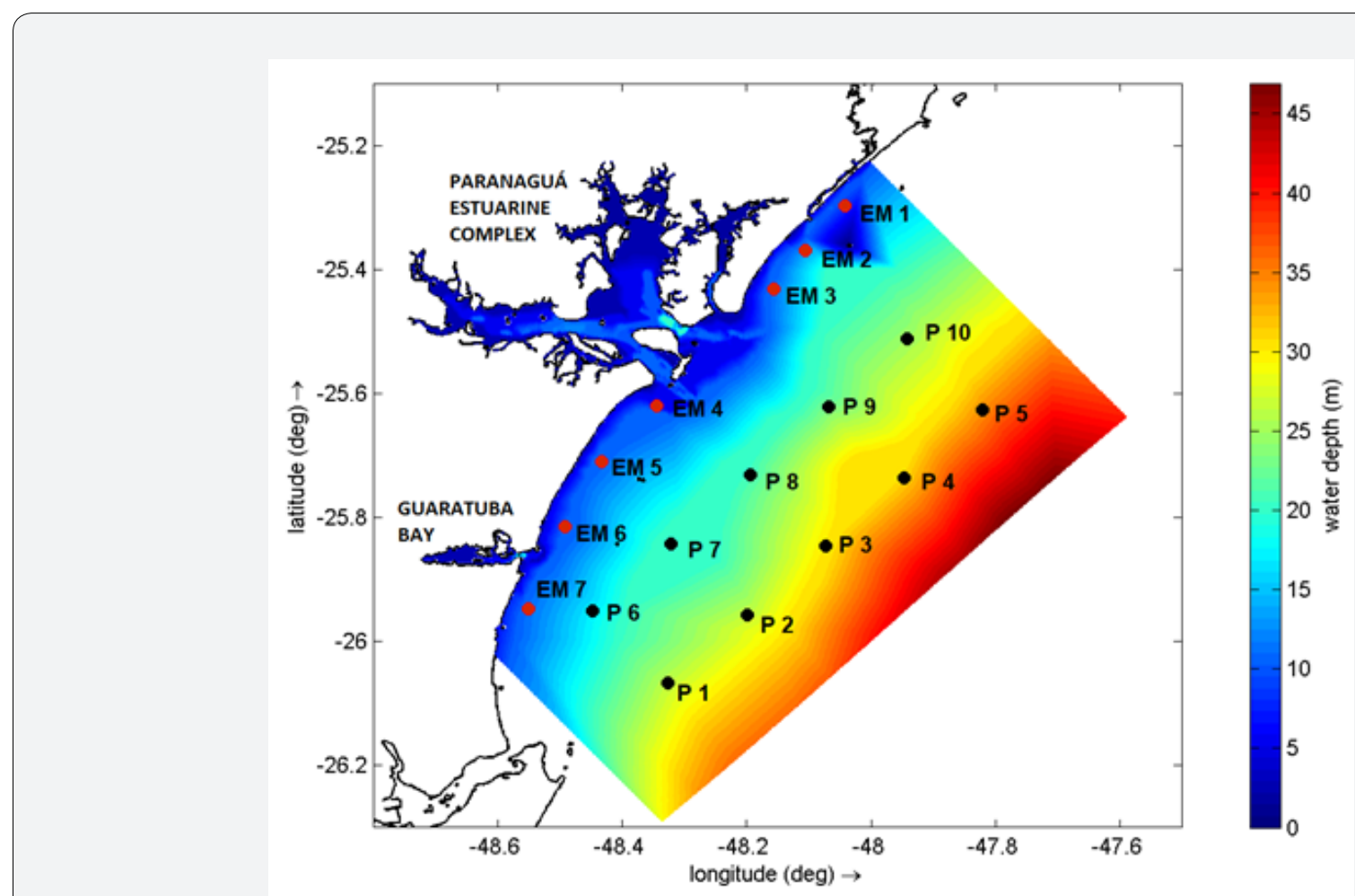

Figure 2: Bathymetry of the grid, selected points for monitoring the model results at the continental shelf (P1 to P10) and selected points for possible submarine outfalls (EM1 to EM7).

The bathymetry of the region was obtained through the digitalization of nautical charts, available on the website of the Marine Hydrographic Center of the Brazilian Navy, in raster format, with maximum depth around 50 meters. Figure 2 presents the bathymetry of the grid, ten monitoring points of model results on the continental shelf (P1 to P10) and seven monitoring points for the discharge points of possible submarine outfalls to be constructed along the coast of the State of Paraná (EM1 to EM7).

\section{FLOW module}

The FLOW module simulates transport phenomena resulting from tide, river discharges and meteorological effects, including the effect of density difference due to horizontal gradients of temperature and salinity fields. The Delft3D - FLOW may be used for flow simulations in seas, coastal regions, estuaries, reservoirs and rivers. This module provides the hydrodynamic conditions used by the other modules, being the first step for any simulation to be developed by the Delft3D program.

Fluvial discharges were considered for both Paranaguá Estuary (eight discharge points) and Guaratuba Bay (one discharge point), with corresponding values of temperature, salinity and flow. For Paranaguá the total river discharges ranged from $63.23 \mathrm{~m}^{3} \cdot \mathrm{s}^{-1}$ in January to $26.44 \mathrm{~m}^{3} \cdot \mathrm{s}^{-1}$ in July, while in Guaratuba from $126.08 \mathrm{~m}^{3} \cdot \mathrm{s}^{-1}$ in January to $50.88 \mathrm{~m}^{3} \cdot \mathrm{s}^{-1}$ in July $[5,17,18]$.

\section{WAQ module}

The water quality module (WAQ) is a three-dimensional model used for representing water quality in natural and artificial en- 
vironments. This module solves the advection-diffusion-reaction equations for a predefined computational grid and several different substances, using the finite element method [19]. In present case, the dispersion of fecal coliforms was simulated, discharged in hypothetical positions for the construction of submarine outfalls, in order to support their construction, based on the premise of minimum influence of contaminants at the coast and adjacent waters.

Table 1: CONAMA Resolution N. ${ }^{\circ} 274 / 2000$ - Limits for Escherichia coli.

\begin{tabular}{|c|c|}
\hline \multicolumn{2}{|c|}{$\begin{array}{c}\text { Saline Water (Salinity } \geq 30 \text { PSU) - Class } \mathbf{1} \text { (primary contact recre- } \\
\text { ation) }\end{array}$} \\
\hline Escherichia Coli & MPN/100mL \\
\hline Proper (Excellent) & 200 \\
\hline Proper (Very good) & 400 \\
\hline Proper (Satisfactory) & 800 \\
\hline
\end{tabular}

(MPN: "most probable number").

When the effluent is discharged in the marine environment through a submarine outfall, a mixing process takes place. This process presents three distinct zones: near-field, intermediate field and far-field [20-22]. Near-field models are used to simulate the blending processes in the region of the initial discharge. For this, they rely on specific information about the effluent discharge, such as number of emitter holes, their dimensions and flows, and environmental characteristics of the receiving body. Far-field models are important for simulations of dispersion of pollutants regardless of how they are released into the marine environment. Therefore, they are commonly used for coastal or estuarine regions or in situations aiming to simulate the dispersion of effluents from previous results of the near field models. In this study, only far-field simulations were performed.

Coliform bacteria have been commonly used in the evaluation of the microbiological quality of the environment [23,24]. In addition to meeting the requirements of a good indicator of fecal contamination, Escherichia coli, one of the species of the coliform group, presents thermotolerant characteristics and habitat restricted exclusively to the intestinal tract of humans and warm-blooded animals. Thus, as they do not occur naturally in the Results

Table 2: Mean comparative statistical parameters obtained for January and July 2016.

\begin{tabular}{|c|c|c|c|c|c|c|c|c|c|}
\hline & & M_D & DP_D & CC & SIGN_CC & MAE & RMAE & RMAE\% & IOA \\
\hline \multirow{4}{*}{ Jan-16 } & Elevation (m) & -0.01 & 0.04 & 0.95 & 0.01 & 0.03 & 0.06 & 6 & 0.98 \\
\hline & Temperature $\left({ }^{\circ} \mathrm{C}\right)$ & 0.32 & 0.66 & 0.68 & 0.04 & 0.62 & 0.17 & 17.44 & 0.76 \\
\hline & EW Comp. (m.s s $\left.^{-1}\right)$ & 0.01 & 0.1 & 0.5 & 0.05 & 0.09 & 0.19 & 18.5 & 0.82 \\
\hline & NS Comp. (m.s $\left.{ }^{-1}\right)$ & -0.03 & 0.11 & 0.57 & 0.05 & 0.1 & 0.15 & 14.88 & 0.89 \\
\hline \multirow{4}{*}{ Jul-16 } & Elevation (m) & 0.08 & 0.04 & 0.95 & 0.01 & 0.08 & 0.14 & 13.88 & 0.9 \\
\hline & Temperature $\left({ }^{\circ} \mathrm{C}\right)$ & -0.13 & 0.38 & 0.54 & 0.05 & 0.42 & 0.24 & 24.12 & 0.64 \\
\hline & EW Comp. (m.s $\left.{ }^{-1}\right)$ & -0.01 & 0.07 & 0.65 & 0.04 & 0.06 & 0.17 & 16.88 & 0.73 \\
\hline & NS Comp. $\left(\mathrm{m} . \mathrm{s}^{-1}\right)$ & 0.01 & 0.1 & 0.48 & 0.05 & 0.08 & 0.17 & 17.06 & 0.82 \\
\hline
\end{tabular}

M_D: Mean difference; DP_D: Difference standard deviation; CC: Correlation coefficient; SIGN_CC: Significance of the correlation coefficient; MAE: Mean absolute error; RMAE: Absolute error in relation to the amplitude; RMAE \%: RMAE percentage; IOA: Index of Agreement. presence of fecal contamination in the environment [25]. According to the Brazilian Council CONAMA, Resolution №. 274/2000, concerning "freshwater, brackish and saline waters intended for bathing (primary contact recreation)", waters considered proper for human use can be subdivided according to Table 1 [26].

In this study, values referring to a nearby outfall, the Praia Grande Submarine Emissary - Subsystem 1 in Sao Paulo State, were used as base for the initial discharge's concentration in Parana State. Information on the concentrations of pollutants discharged by Praia Grande emissary, during summer and winter seasons, was obtained from SABESP [27] and Yang \& Harari [28]. Thus, in the simulations of the far field model, the following values of $E$. coli were used for hourly discharges, $3.17 \times 10^{5} \mathrm{MPN} / 100 \mathrm{~mL}$ and $1.36 \times 10^{5} \mathrm{MPN} / 100 \mathrm{~mL}$, for summer and winter respectively, in five levels equally spaced along the vertical, for the seven emissaries proposed in this study. Standard values were used for other Delft3D-WAQ parameters [19]. In order to identify the pollution of the marine environment exclusively from the proposed submarine emissaries, zero concentration of fecal coliform was defined as the initial condition for all the grid points.

In this study, time series from the Copernicus Marine Environment Monitoring Service (CMEMS) database were used for validation of the Delft3D model, by comparing mean sea level elevation, and surface values of temperature, East-West component (EW) and North-South component (NS) of currents. The validation used data from the observational points on both the continental shelf and emissary points (Figure 2).

For a complete analysis of the data, some statistical parameters were used: the means of the differences between the results of the two models (M_D), the standard deviation of these differences (DP_D), the correlation coefficient between Delft3D and CMEMS time series (CC), the significance of the correlation coefficient (SIGN_CC), the mean absolute error (MAE), the absolute error in relation to the amplitude (RMAE), the percent absolute error in relation to the amplitude (RMAE\%), and the Willmott [29] index of agreement (IOA). environment, this species constitutes an excellent indicator for the

\section{Model validation}




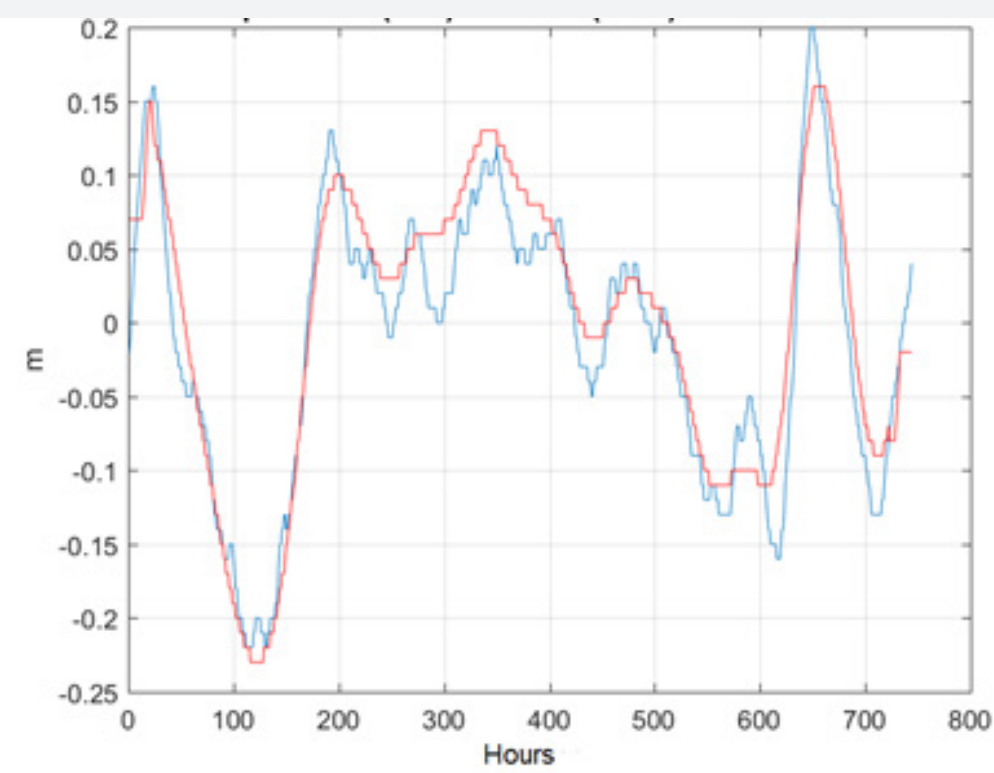

Figure 3: Comparison between mean sea surface elevation time series for Delft3D (red) and CMEMS.

To analyze the model results for the months of January and cedure corresponds to the "heating" of the model, allowing the July 2016, the model was processed starting from rest in the January and July 2016 analyses to be performed without the influmonths of December 2015 and June 2016, respectively. This pro- ence of a resting state initial condition.

\section{Validation}

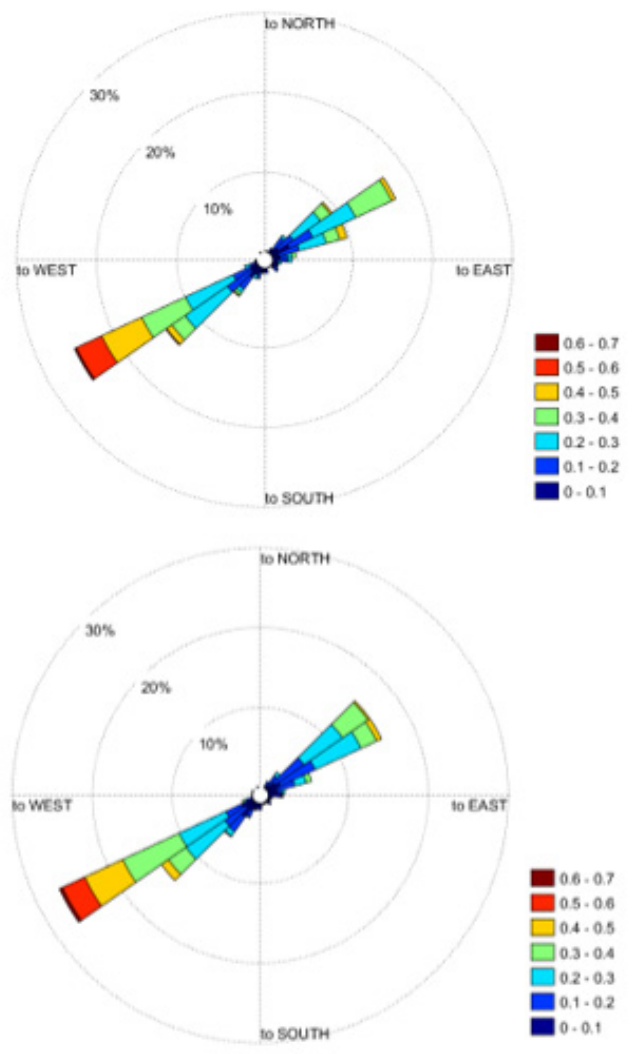

Figure 4: Angular histograms of surface currents (m.s_1), for the EM4 position, in January 2016 (above) and July 2016 (below). 
For the comparison between the results from the Delft3D model and the values obtained through the CMEMS database, statistical calculations and graphs of the respective time series were performed, for points P1 to P10 and EM1 to EM7. As an example, the comparison between the time series of sea level elevation for the $\mathrm{P} 5$ position, located on the continental shelf, are shown on Figure 3. Table 2 presents the mean statistical parameters for all the analyzed positions (P01 to P10 and EM1 to EM7).

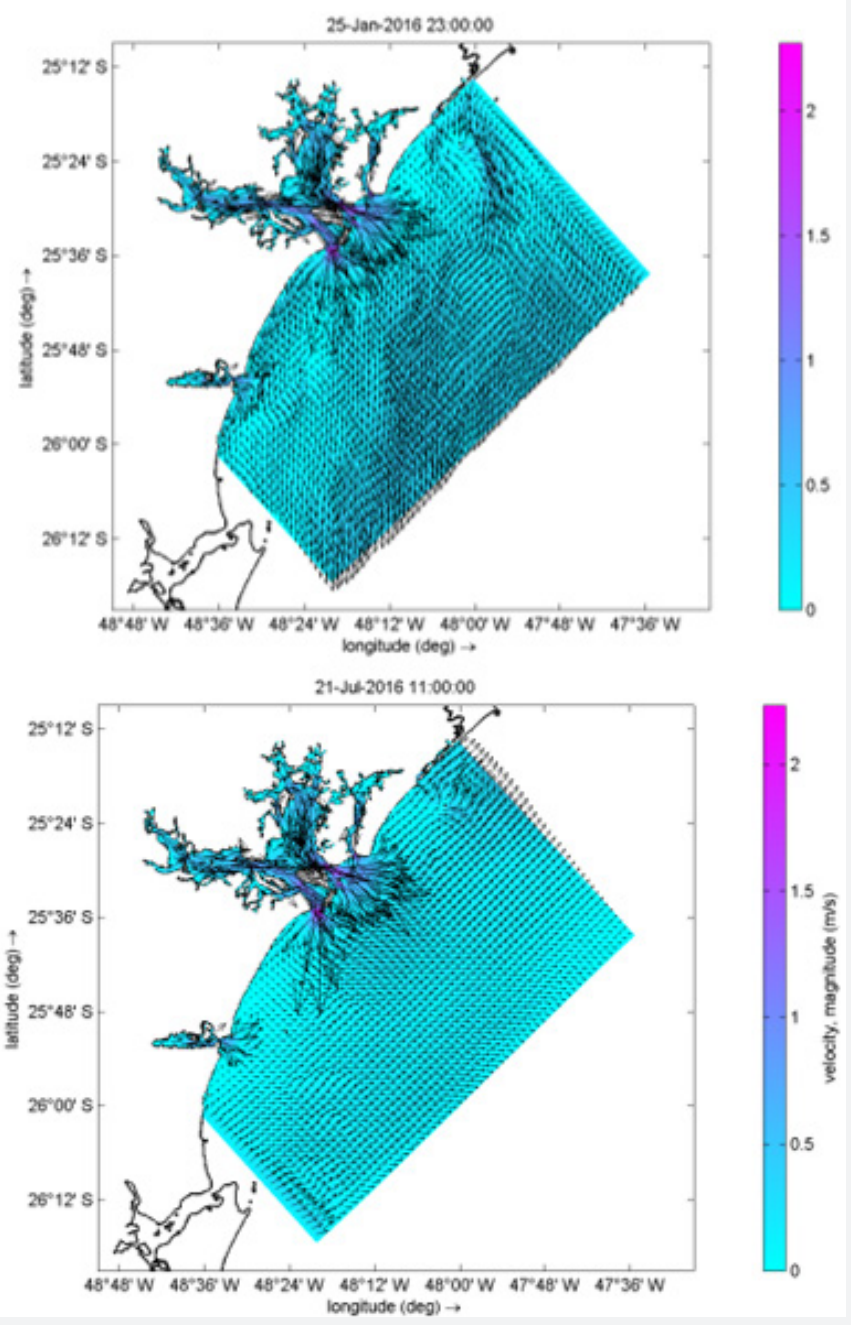

Figure 5: Surface current distributions (m.s-1), at times of maximum current intensity for EM4, on January 25th 23:00, and on July 21st 11:00.

\section{Hydrodynamic model}

An example of the circulation model output is given on Figure 4 , with the angular histograms of the surface currents at point EM4, on January and July 2016.

\section{Distribution of hydrodynamic properties}

Examples of surface current distributions computed by FLOW module are given on Figure 5, referent to times of maximum current intensity for EM4, with corresponding values of 0.62 and $0.61 \mathrm{~m} . \mathrm{s}^{-1}$, which occurred on January $25^{\text {th }}$ at $23: 00$, and on July $21^{\text {st }}$ at $11: 00$.

\section{Water quality model}

Using Delft3D-WAQ module, E. coli concentration time series were obtained for all emissary points, for several depth levels. The results for point EM4, at the surface, in January and July 2016, are shown on Figure 6. These results are relative to OBS1, the precise location of the emissary, and at OBS5, at a distance of $1400 \mathrm{~m}$ from EM4 towards the coastline, including the levels of satisfactory, very good and excellent water quality, following the limits of CONAMA Resolution №. 274/2000 (Table 1).

\section{Plume distribution}

Figures $7 \& 8$ show the distribution of $E$. coli plumes at the times of maximum concentration and maximum dispersion from emissary EM4, in January and July 2016. At the times of maximum concentration, the limit for satisfactory water quality was exceeded, respectively on January $3^{\text {rd }}$ 09:00 and July $27^{\text {th }}$ 08:00 (see Figure 6); the times of maximum dispersion were January $25^{\text {th }} 23: 00$ and July $21^{\text {st }} 11: 00$ 

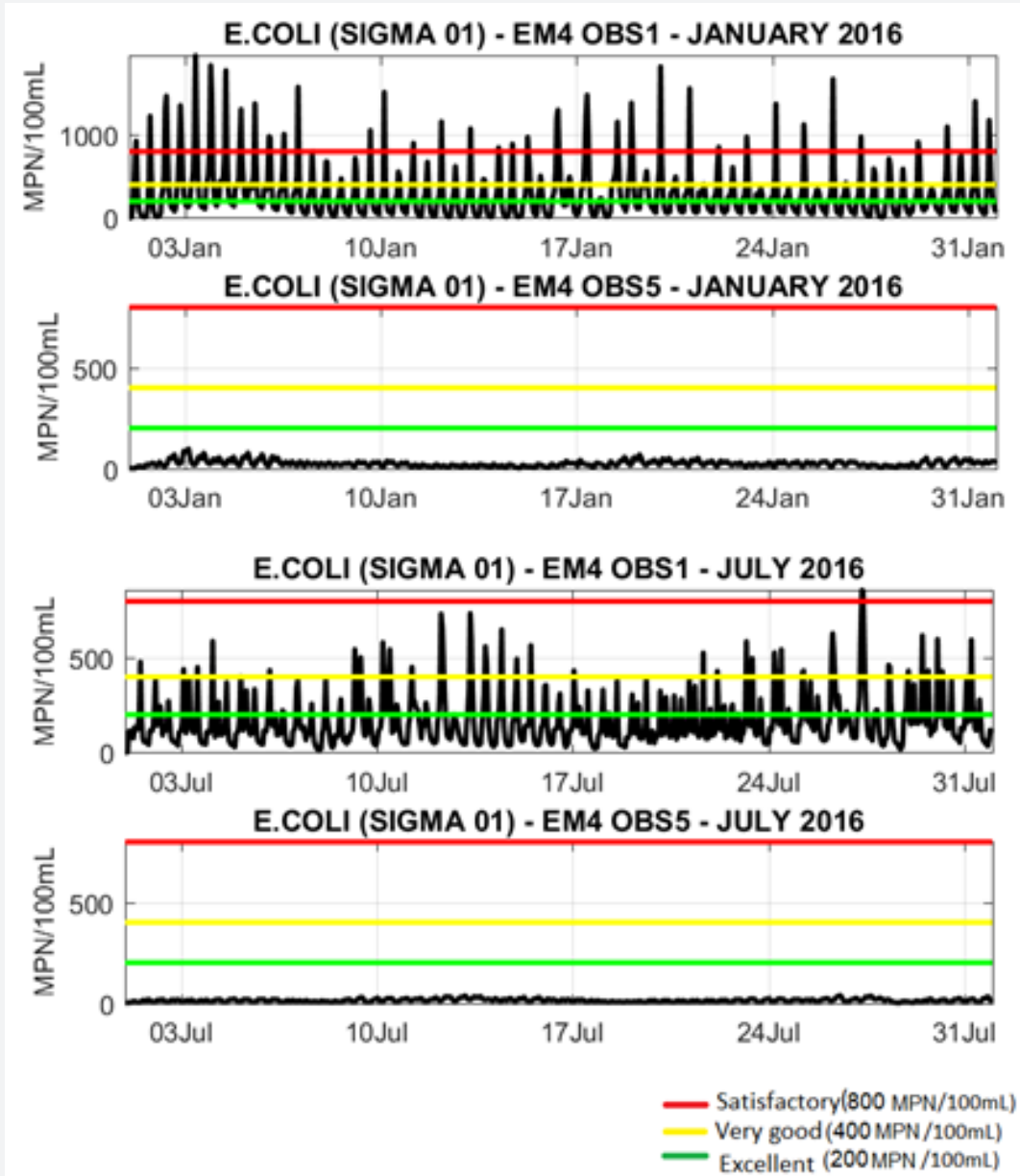

Figure 6: Time series of E.coli surface concentration, at the precise location of the emissary EM4 (OBS1) and 1400m from EM4 towards the coastline (OBS5), throughout January 2016 (above) and July 2016 (below).

\section{Discussion}

The results for both the FLOW (hydrodynamic) and the WAQ (water quality) modeling, at the different points selected along the coast and on the adjacent continental shelf, allowed a complete analysis of the hydrodynamic conditions and dispersion of pollutants in the coastal region of the State of Paraná, especially in relation to the proposed sites for the construction of submarine emissaries (Figure 2). The results obtained in the research and analyses are discussed below, especially for emissary EM4, located near the Paranaguá Estuarine Complex, with biggest population involved and most important economic region of the study area.

\section{Validation}

The comparison between the results from the Delft3D coastal model (with horizontal resolution of $350 \mathrm{~m}$ ) and the values obtained through the CMEMS global database (with horizontal resolution of about $9 \mathrm{~km}$ ) suggest that the coastal model can be considered as fully validated. In terms of dispersion analysis, the most important hydrodynamic parameter is the horizontal current, which presented Index of Agreement IOA above 0.73 and percent absolute error in relation to the amplitude below 20\% (Table 2).

\section{Hydrodynamic model}

Results from the hydrodynamic simulation reproduced well known characteristics of the shelf circulation, especially the influence of the meteorological conditions. The general features do not differ from summer to winter, as the angular histograms of January and July are very similar (Figure 4). On the other hand, frontal systems significantly change the current patterns at the continental shelf, as presented on Figure 5, which represents the standard circulation and the circulation under the effect of a cold front, although within Paranaguá Estuary and Guaratuba Bay, and adjacent areas, the tides act as primary effect. It is worth noting that cold fronts occur both on summer and winter months, and although being in general stronger and more frequent in winter, for the simulated months of 2016, the cold system at the beginning of January had stronger effect than that at the end of July.

\section{Water quality model}

For the analysis of the dispersion of pollutant's plumes, the focus is on the pollutants concentration between the discharge 
points and the coastline, by comparing the model results to the CONAMA limits of water quality.

When dealing with submarine emissaries, the "Legal Mixture
Zone" is defined as a region where the parameters of the contaminants are above the limits established by legislation. In practice, this region is admittedly a zone of sacrifice. The better the emissary, the smaller the mixture zone will be [30].

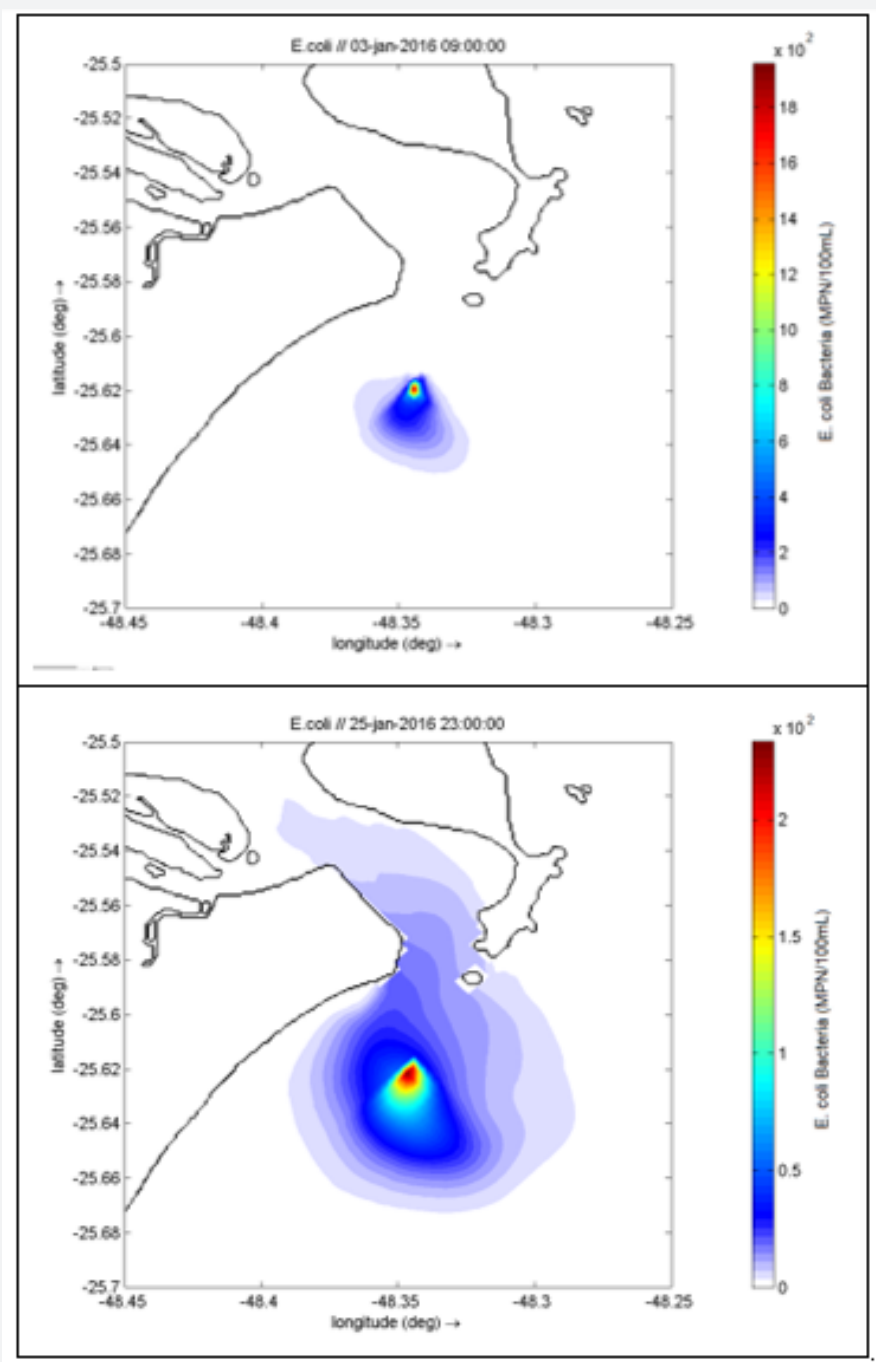

Figure 7: E. coli's surface pollutant plumes from submarine outfall EM4 in January 2016: maximum concentration (above) and maximum dispersion (below).

The E. coli concentration time series for EM4 and nearby point (1440m towards the coastline), for January and July, present several periods with very high values at the discharge point, exceeding the limit established for the satisfactory quality $(800 \mathrm{NMP} / 100 \mathrm{~mL})$; however, more than $1 \mathrm{~km}$ away from the discharge point, the concentrations are negligible (Figure 6) [31].

Figures $7 \& 8$, corresponding to the E. coli plumes in the vicinity of EM4, at the times of maximum concentration and maximum dispersion, in January and July respectively, show that for the position of the proposed emitter, high concentrations are limited to regions close to the points of effluent discharge, without reaching deeper areas or the coastline.
The characteristics of the pollutants dispersion here presented and analyzed for EM4 were also observed for the remaining emissaries.

\section{Conclusion}

The hydrodynamic results obtained are consistent with previous studies carried out in the region. The analysis of the dispersion associated to all seven emissaries proposed along the coast of the State of Paraná, through the representation of the E. coli distributions, indicates that high concentrations are limited to the regions very close to the effluent discharge points, proving that the local current systems do not cause the return of pollution towards the coast. It is important to remember that the use 
of submarine emissaries is associated with a Legal Mixing Zone, where concentrations of pollutants are still high, and constitute an area of environmental sacrifice.

The use of submarine outfalls for the efficient treatment of sewage has become increasingly common around the world. Effluent disposal in the ocean is an efficient, rapid and sustainable way to manage effluents. When considering the alternatives to improve the sewage treatment system in Paraná State, submarine outfalls are an excellent choice, due to their high efficiency, low cost and limited environmental impact. But the implementation and management of submarine outfalls must be done with suitable modeling of both hydrodynamics and dispersion, together with monitoring programs based on field measurements, to validate the models.

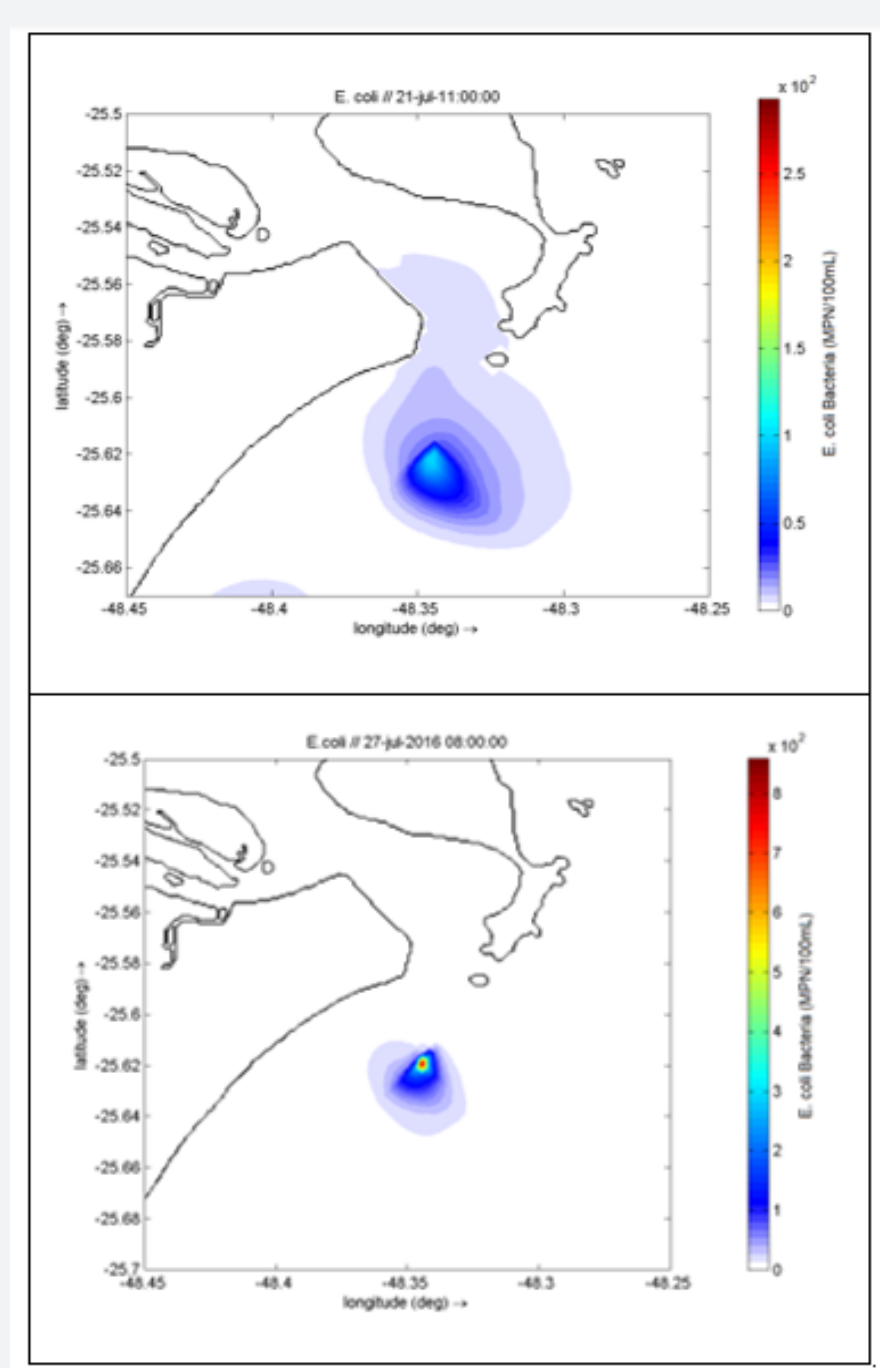

Figure 8: E. coli's surface pollutant plumes from submarine outfall EM4 in July 2016: maximum dispersion (above) and maximum concentration (below).

\section{Acknowledgements}

To Institute of Oceanography (IO-USP) and Institute of Energy and Environment (IEE-USP) of the University of Sao Paulo, for their support to authors. To Conselho Nacional de Desenvolvimento Científico e Tecnológico (CNPq), for providing a scholarship to Paola Galluzzi Polesi.

\section{References}

1. Camargo R, Marone E (1995) Comportamento do vento de superfície em Pontal do Sul (PR, Brasil): análise preliminar. Congresso Latino Americano de Ciências do Mar. 63-63.
2. Castro BM (2005) Multidisciplinary oceanographic processes on the western Atlantic continental shelf between $4^{\circ} \mathrm{N}$ and $34^{\circ} \mathrm{S}(4, \mathrm{~W})$. In: Robinson AR, Brink KH (Eds.), The Sea 14: 259-293.

3. Quadros CJL, Marone E, Angulo RJ, Martins GJ, Bento JPN (2007) Dinâmica morfosedimentar associada à incidência de sistemas frontais em duas praias do litoral paranaense. Boletim Paranaense de Geociências 60: 65-74.

4. Soares ID, Möller O (2001) Low-frequency currents and water mass spatial distribution on the southern Brazilian shelf. Continental Shelf Research 21(16-17): 1785-1814.

5. Ribas TM (2004) Implementação de Modelo Numérico para Estudo Hidrodinâmico das Baías de Antonina e de Paranaguá - PR . Curitiba: Universidade Federal do Paraná. 
6. Lamparelli CC (2007) Desafios para o licenciamento e monitoramento ambiental de emissários: a experiência de São Paulo. In: Lamparelli CC, Ortiz JP (Eds.), Emissários Submarinos: Projeto, avaliação de impacto ambiental e monitoramento. São Paulo, Secretaria do Meio Ambiente, p. 240.

7. Arasaki E, Ortiz JP (2007) Critérios de decisão aplicados aos emissarios submarinos no litoral paulista. Emissários submarino: projeto, avaliação de impacto ambiental e monitoramento = Submarine outfalls: design, compliance and environmental monitoring, CETESB, São Paulo, Brazil.

8. Knill MW (1984) Outfalls versus Inland Treatment. The Public Health Engineer 12 (2).

9. Noernberg MA, Angelotti R, Caldeira GA, Ribeiro De Sousa AF (2008) Determinação da sensibilidade do litoral paranaense à contaminação por óleo. Brazilian Jornal of Aquatic Science and Technology 12(2): 4959.

10. Deltares (2019) Delft Dashboard (DDB) - Open Earth - Deltares - Publicwiki.deltares.nl.

11. Saha S, et al. (2011) updated daily. NCEP Climate Forecast System Version 2 (CFSv2) 6-hourly Products. Research Data Archive at the National Center for Atmospheric Research, Computational and Information Systems Laboratory.

12. Egbert GA, Bennett AF, Foreman MGG (1994) TOPEX/POSEIDON tides estimated using a global inverse model. Journal of geophysical research. 99(C12): 24821-24852.

13. Egbert GA (2002) Efficient inverse modeling of barotropic ocean tides. Journal of atmospheric and oceanic technology 19(2): 183-204.

14. Copernicus (2019) Home - Copernicus.

15. Nouel L (2018) PRODUCT USER MANUAL For the GLOBAL Ocean Sea Physical Analysis and Forecasting Products GLOBAL_ANALYSIS_FORECAST_PHY_001_024 (version 3.2), 16 p. Accessed on 20 aug 2018.

16. Deltares (2014a) Manuals - Delft3D-FLOW - oss.deltares.nl.

17. TCP (2008) Terminal de Contêineres de Paranaguá. Relatório de Impacto Ambiental - Ampliação do Cais, p. 109.

18. Mantovanelli A (1999) Caracterização da dinâmica hídrica e do material particulado em suspensão da Baía de Paranaguá e em sua bacia de drenagem. Curitiba: Universidade Federal do Paraná 51.

19. Deltares (2014b) Manuals - Delft3D-Water Quality - oss.deltares.nl.

20. Gregorio HP (2009) Modelagem numérica da dispersão da pluma do emissário submarino de Santos. Master's degree. Oceanographic Insti- tute, University of São Paulo (IO-USP), Brazil, p.108.

21. Delfim V (2011) Modelagem e análise do lançamento de efluentes através de emissário submarino - Região do Campeche, Florianópolis, SC. Bachelor's degree, Centro de Ciências Tecnológicas da Terra e do Mar da Universidade do Vale do Itajaí (CTTMar - Univali), p. 66.

22. Subtil EL (2012) Tratamento de águas residuárias utilizando emissários submarinos: avaliação do nível de tratamento para uma disposição oceânica absolutamente segura. Phd. Polytechnic School from the University of São Paulo (EPUSP), Brazil, p. 218.

23. Rompré A, Servais P, Baudart J, de-Roubin MR, Laurent P (2002) Detection and enumeration of coliforms in drinking water: current methods and emerging approaches. J Microbiol Methods 49(1): 31-54.

24. Tallon P, Magajna B, Lofranco C, Leung KT (2005) Microbial indicators of fecal contamination in water: A current perspective. Water Air and Soil Pollution 166(1-4): 139-166.

25. CETESB (2012) Norma técnica. Escherichia coli: Determinação pela técnica de membrana filtrante em amostras de águas - método de ensaio. (2 $\left.2^{-\mathrm{a}} \mathrm{edn}\right), \mathrm{L} 5.230$, p. 21.

26. CONAMA (2001) Resolução CONAMA № 274/2000 - "Revisa os critérios de Balneabilidade em Águas Brasileiras". Data da legislação: 29/11/2000 - Publicação DOU no 018, de 08/01/2001, pp. 70-71.

27. SABESP (2006) Prestação de serviços referentes à execução dos programas de monitoramento ambiental da área sob influência do emissário submarino de esgotos de Santos / São Vicente e de monitoramento ambiental da área sob influência dos emissários submarinos de esgotos de Praia Grande - Subsistemas 1, 2 e 3. Relatório técnico. Vol. II (Avaliação do monitoramento de Praia Grande), N.o 501. São Paulo (SP), Brazil, p. 380.

28. Yang SH, Harari J (2016) Modeling Extreme Conditions of Sewage Plumes in Central - South Coastal Region of São Paulo State - Brazil. Revista do Departamento de Aguas e Esgotos, São Paulo (Revista DAE), edição 204, p. 73-80.

29. Willmott CJ (1982) Some comments on the evaluation of the model performance. Bulletin of the American Meteorological Society 63(11): 1309-1313.

30. Alfredini P (2005) Obras e Gestão de Portos e Costas. Edgard Blucher (Ed.).

31. Marone EM, Mantovanelli A, Noernberg MA, Klingenfuss MS, Lautert LF, et al. (1997) Caracterização física do complexo estuarino da Baía de Paranaguá-Relatório consolidado do convênio APPA/CEM. Pontal do Paraná: UFPR.

\section{Your next submission with Juniper Publishers will reach you the below assets}

- Quality Editorial service

- Swift Peer Review

- Reprints availability

- E-prints Service

- Manuscript Podcast for convenient understanding

- Global attainment for your research

- Manuscript accessibility in different formats

( Pdf, E-pub, Full Text, Audio)

- Unceasing customer service

Track the below URL for one-step submission https://juniperpublishers.com/online-submission.php 